\title{
KAJIAN PERUBAHAN PARAMETER SENSORI DENGAN METODE DEMERIT POINT SCORE PADA PENURUNAN KESEGARAN IKAN PATIN SELAMA PENGESAN
}

\section{Study on the Changes of Sensory Parameters using Demerit Point Score Method on Deterioration Process of Fresh Pangasius during Ice-Storage}

\author{
Farida Ariyani", Irma Hermana, Radestya Triwibowo dan Singgih Wibowo \\ Pusat Penelitian dan Pengembangan Daya Saing Produk dan Bioteknologi Kelautan dan Perikanan, \\ JI. K.S. Tubun Petamburan VI, Jakarta Pusat, Indonesia \\ Korespondensi Penulis: idapoernomo@yahoo.co.id \\ Diterima : 25 Februari 2016; Disetujui : 29 April 2016
}

\begin{abstract}
ABSTRAK
Penelitian ini bertujuan untuk mempelajari perubahan parameter sensori pada penurunan kesegaran ikan patin (Pangasius hypopthalmus) selama pengesan menggunakan metode demerit point score (DPS). Percobaan dilakukan dengan mematikan ikan patin secara hypothermia, menyusunnya dalam kotak berinsulasi yang berisi es dengan perbandingan es : ikan = 2:1 (b/b), dan menyimpan kotak tersebut pada suhu ruang. Penggantian es yang mencair dilakukan setiap hari. Penurunan kesegaran ikan diamati secara sensori berdasarkan metode demerit point score (DPS) selama 25 hari dengan interval waktu pengamatan setiap 5 hari terhadap atribut kenampakan, mata, insang, perut, anus dan rongga perut menggunakan skala 0-3 untuk setiap parameter pada masing-masing atribut. Hasil kajian menunjukkan bahwa parameter utama yang menentukan perubahan sensori secara signifikan pada patin segar adalah kenampakan dan kekakuan pada atribut kenampakan umum, kejernihan dan bentuk pada atribut mata, warna dan bau pada atribut insang, bau pada atribut anus, dan stains pada atribut rongga perut. Adapun beberapa parameter yang relevansinya rendah terhadap penilaian panelis pada penurunan kesegaran patin antara lain lendir permukaan pada atribut kenampakan umum, darah pada atribut mata, lendir pada atribut insang, kekakuan dan diskolorasi pada atribut perut, dan kondisi pada atribut anus, sedangkan parameter kulit tidak memiliki relevansi terhadap penilaian panelis pada penurunan kesegaran patin. Berdasarkan penilaian panelis terhadap semua atribut, lama penyimpanan patin segar yang dinyatakan ditolak panelis adalah 25 hari.
\end{abstract}

KATAKUNCI: sensori, demerit point score, patin, kesegaran, penyimpanan dalam es

\begin{abstract}
This research aimed to investigate the changes of sensory parameters using demerit point score (DPS) method on deterioration process of fresh pangasius (Pangasius hypopthalmus) during ice-storage. Trial was done by hypothermia killing of live pangasius (immersing in ice water), and arranging them in insulated boxes covered with crushed ice with the proportion of ice and fish of $2: 1(w / w)$. The insulated boxes containing fish were kept at ambient temperature and melted ice was changed daily. The decreasing of freshness was evaluated every 5 days for 25 days using demerit point score (DPS) for several atributes, i.e., appearance, eyes, gills, belly, vent, and belly cavity. Every parameter within atribute was scored from 0 to 3. Result of the study showed that the main parameters strongly correlated with freshness decreasing were appearance and body stiffness, eyes form and clarity, gills colour and odour, vent odour, and stains of belly cavity, while parameters with low correlation to freshness decrease were surface mucus, blood of eyes, gills mucus, stiffness and discoloration of belly and condition of vent. There was one parameter, that had no correlation to freshness deterioration namely skin. Based on panelists assessment of all attributes, pangasius was rejected on the storage of 25 days.
\end{abstract}

KEYWORDS: sensory, demerit point score, pangasius, freshness, ice storage 


\section{PENDAHULUAN}

Penanganan ikan segar merupakan salah satu bagian penting dari industri perikanan karena untuk semua jenis produk, kesegaran merupakan faktor penting yang menentukan kualitas produk akhir. Kandungan air dan protein yang tinggi pada ikan menyebabkan ikan cepat mengalami proses pembusukan. Terdapat banyak cara untuk menunda terjadinya proses pembusukan dari ikan, akan tetapi cara yang paling ideal adalah menggunakan sistem rantai dingin (Ghaly, Dave, Budge \& Brooks, 2010). Prinsip dari sistem ini adalah mempertahankan ikan dalam kondisi dingin sampai ikan siap diolah.

Kesegaran dapat diamati melalui parameter sensori, biokimia, mikrobiologi dan fisik. Analisis secara sensori merupakan analisis yang relatif lebih mudah dibandingkan dengan analisis secara kimiawi maupun mikrobiologi karena tidak memerlukan peralatan yang relatif mahal dengan waktu analisis yang relatif lama (Heinz \& Hautzinger, 2007).

Kelebihan analisis sensori ini akan sangat relevan apabila digunakan untuk mengetahui kemunduran kesegaran produk perikanan karena kecepatan proses deteriorasi ikan lebih cepat dibandingkan dengan produk pangan lain (Green-Petersen, 2010; Lillian, Einarsson \& Eythorsdottir, 2007).

Perubahan pada atribut sensori terjadi pada kenampakan, bau, rasa dan tekstur ikan yang mengalami deteriorasi. Perubahan sifat sensoris ikan sesudah mati sangat bervariasi tergantung jenis ikan dan cara penyimpanan. Beberapa metode uji sensori telah dikembangkan, termasuk metode Indek Kualitas yang didasarkan pada demerit point scores (DPS) dengan pengertian bahwa semakin rendah nilai hasil assessment panelis semakin tinggi kualitas ikan (Huss, 1995). Peneliti dari Tasmanian Food Research Unit Australia pertama kali mengembangkan metoda DPS yang merupakan metode yang relatif mudah dan cepat dengan didasarkan pada penilaian deskriptif yang dikuantifikasikan untuk menentukan kualitas kesegaran ikan (Branch \& Vail, 1985; Bremner, Statham \& Sykes, 1985). Penilaian DPS meliputi atribut kenampakan umum, mata, insang, perut, anus dan rongga perut dan nilai untuk setiap atribut diset pada kisaran 0-3 dengan nilai nol untuk ikan dengan kesegaran prima, dan nilai tiga untuk atribut ikan yang telah mengalami deteriorasi lanjut. Jumlah dari semua poin untuk semua parameter merupakan nilai demerit point score yang kemudian dikenal sebagai indek kualitas (Huidobro, Pastor \& Tedaja, 2000). Pola perubahan atribut pada proses deteriorasi ikan tidak selalu sama untuk semua jenis ikan, dan penggunaan metode DPS pada penilian kesegaran ikan dinyatakan spesifik untuk setiap spesies, sehingga diperlukan pengembangan DPS untuk tiap spesies ikan (Bernardi Mársico \& de Freitas, 2013; Hyldig, Bremner, Martinsdottir \& Schelvis, 2007; Hyldig \& GreenPeterson, 2004; Huidobro et al.; Rahman \& Olley, 1984; Luten et al. 1997; Sant'Ana, Soares \& VasPirez, 2011; ).

Ikan patin merupakan jenis ikan konsumsi air tawar bertubuh panjang, berwarna putih perak dengan punggung berwarna kebiruan. Dibandingkan dengan ikan kerapu dan ikan nila, ikan patin tidak bersisik dan mempunyai daging dengan tingkat kekenyalan yang relatif tinggi sehingga potensi pemanfaatannya sebagai bahan baku surimi dan diversifikasi produknya cukup tinggi. Pada tahun sebelumnya telah dilakukan penelitian penurunan kesegaran filet patin selama pengesan melalui pengamatan secara sensori menggunakan metoda American Society for Testing and Materials/ASTM (Ikasari \& Suryaningrum, 2015), sedangkan terhadap ikan utuh telah dilakukan pengamatan penurunan kesegaran pada ikan nila dan kerapu yang diamati secara sensori dengan metoda DPS (Ariyani \& Dwiyitno, 2010; Ariyani, Murtini \& Andayani, 2011, Ariyani, Yenni \& Riyanto, 2014). Dengan mempertimbangkan karakteristik fisik ikan patin yang spesifik dan berbeda dengan nila dan kerapu, maka penelitian ini bertujuan untuk mengetahui pola kemunduran mutu ikan patin selama pengesan melalui pengamatan atribut sensori dengan metoda DPS.

\section{BAHAN DAN METODE}

\section{Bahan}

Bahan baku yang digunakan pada penelitian ini adalah ikan patin (Pangasius hypopthalmus) hidup yang diperoleh dari pembudidaya di daerah Parung, Bogor dengan ukuran berat $660-700 \mathrm{~g}$ dan panjang 46-51 cm. Pemilihan ikan hidup didasarkan pada pertimbangan agar diperoleh data kesegaran ikan yang prima (segera setelah ikan mati).

\section{Metode}

Ikan patin hidup dibawa ke Laboratorium Balai Besar Penelitian dan Pengembangan Daya Saing Produk dan Bioteknologi Kelautan dan Perikanan (BBP4B-KP), Jakarta dengan menggunakan teknik transportasi basah. Ikan dimasukkan ke dalam kantong plastik yang berisi air dan oksigen, kemudian dimasukkan ke dalam styrofoam dan dibawa ke Laboratorium BBP4B-KP. Selanjutnya ikan dimatikan dengan cara pengesan (hypothermia) dan disimpan pada suhu dingin (dalam cool box berisi es dengan perbandingan ikan : es $=1: 2 \mathrm{~b} / \mathrm{b}$ ). Pengamatan dilakukan setiap 5 hari selama 25 hari terhadap parameter sensori dengan metoda DPS (Branch \& Vail, 1985) oleh 6 panelis terlatih (BSN, 2011). 
Atribut sensori yang dinilai meliputi kenampakan umum, mata, insang, perut, anus dan rongga perut. Masing-masing atribut tersebut dijabarkan ke dalam beberapa parameter. Atribut kenampakan umum terdiri dari parameter kenampakan, kulit, lendir permukaan dan kekakuan; atribut mata terdiri dari parameter kejernihan, bentuk, pupil dan darah; atribut insang terdiri dari parameter warna, lendir dan bau; atribut perut terdiri dari parameter diskolorasi dan kekakuan; atribut anus terdiri dari parameter kondisi anus dan bau; atribut rongga perut terdiri dari parameter stains dan darah. Skala penilaian untuk masing-masing parameter adalah 0-3, dengan kriteria nol berkualitas prima dan tiga berkualitas rendah. Nilai setiap atribut merupakan penjumlahan nilai dari semua parameternya, dan penjumlahan dari semua nilai atribut merupakan total DPS dengan nilai maksimal 36 (Lampiran 1). Percobaan dilakukan dengan lima kali ulangan.

Analisis secara statistik dilakukan dengan metoda analisis komponen utama (principal component analysis) atau PCA, untuk melihat relevansi parameter sensori dalam setiap atribut terhadap penurunan kesegaran ikan. Pengujian statistik dilakukan menggunakan perangkat lunak Past Statistical Software v3.08 (Hammer, Harper \& Ryan, 2001).

\section{HASIL DAN BAHASAN}

Selama penyimpanan dalam es, terjadi perubahan yang bervariasi pada parameter sensori ikan patin. Untuk mengetahui perubahan setiap parameter sensori secara lebih jelas, data hasil pengamatan untuk semua parameter dianalisis menggunakan PCA. Prinsip umum dari PCA adalah menyederhanakan beberapa variable menjadi dua atau tiga faktor yang dilakukan dengan menentukan kesesuaian letak variabel terhadap garis axis. Variabel-variabel yang dekat dengan garis horizontal dikelompokkan sebagai faktor komponen 1 (PCA 1), selanjutnya variabelvariabel yang dekat dengan garis vertikal dikelompokkan sebagai faktor komponen 2 (PCA 2). PCA sering digunakan untuk membantu dalam menentukan pemilihan atribut sensori yang akan dituangkan ke dalam lembar penilaian (Hyldig et al., 2007). Hasil analisis menggunakan PCA disajikan pada Gambar 1.

Berdasarkan tampilan hasil PCA pada Gambar 1, terlihat bahwa parameter yang termasuk ke dalam faktor komponen 1 (PCA 1) dengan relevansi tinggi $(65,28 \%)$ terhadap penilaian panelis, merupakan parameter yang mendekati garis horizontal (sumbu x) yaitu kenampakan, warna insang, kekakuan badan, kejernihan mata, bentuk mata, pupil mata, bau insang,

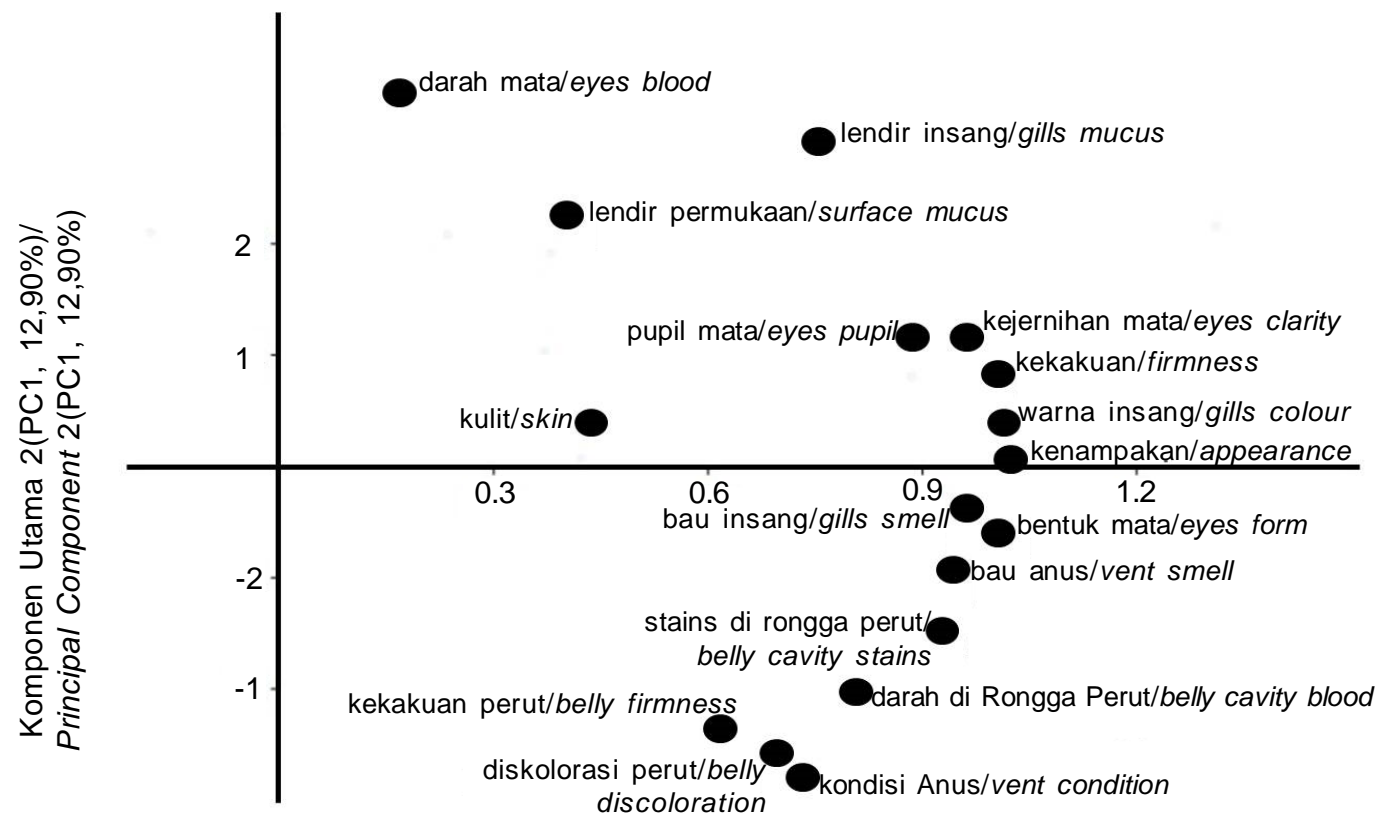

Komponen Utama 1 (PC1, 65,28\%)/Principal Component 1 (PC1, 65,28\%)

Gambar 1. Tampilan hasil PCA terhadap semua parameter sensori pada patin segar selama pengesan. Figure 1. PCA describing all sensory parameters of fresh pangasius during ice-storage 
bau anus, dan stains rongga perut. Parameter yang termasuk ke dalam faktor komponen 2 (PCA 2) merupakan parameter yang mendekati garis vertikal (sumbu y) dan mempunyai relevansi rendah (12,90\%) terhadap penilaian panelis, termasuk di dalamnya adalah darah di mata, lendir permukaan, lendir insang, kekakuan perut, diskolorasi perut, kondisi anus dan darah rongga perut. Sangat berbeda dengan parameter lainnya, parameter kulit tidak terhubung ke faktor manapun.

Untuk memperjelas dan mengkonfirmasi hasil PCA, perubahan pada masing-masing parameter sensori selanjutnya dituangkan ke dalam grafik (skor/ DPS versus waktu penyimpanan) pada masing-masing parameter untuk setiap atribut (Gambar 2-7).

\section{Atribut Kenampakan Umum}

Dalam mendapatkan nilai atribut kenampakan umum dilakukan melalui penilaian terhadap empat
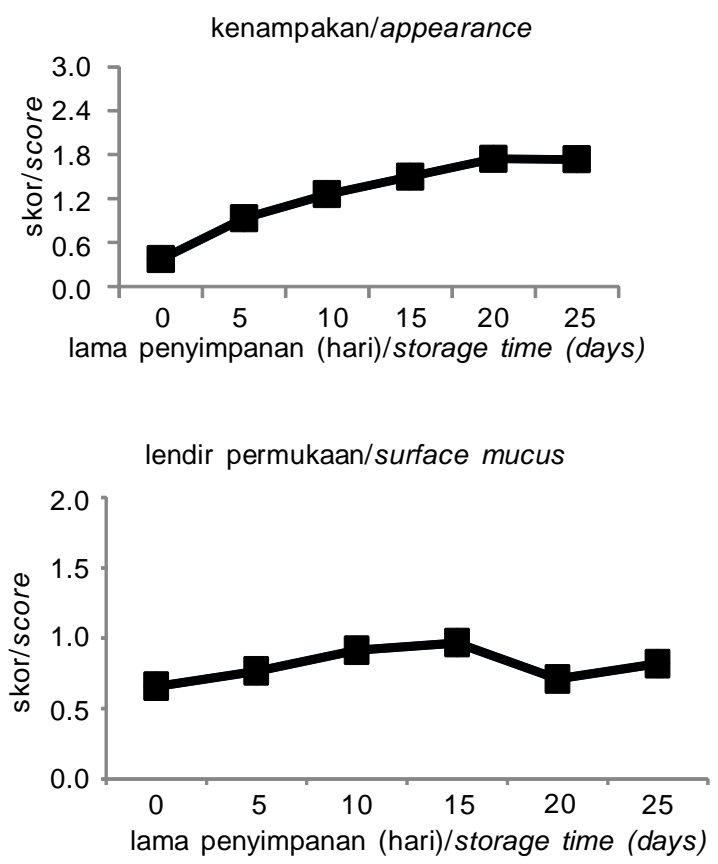

parameter terkait kenampakan umum tubuh ikan, yaitu kenampakan, kulit, lendir permukaan dan kekakuan. Gambar 2 menunjukkan perubahan skor penerimaan panelis terhadap atribut kenampakan umum.

Berdasarkan penilaian panelis, dengan bertambahnya waktu penyimpanan, skor akan meningkat yang menunjukkan terjadinya penurunan mutu karena proses deteriorasi selama penyimpanan. Pada atribut kenampakan umum, parameter yang menunjukkan korelasi positif antara skor dengan waktu penyimpanan adalah kenampakan dan kekakuan, sedangkan pada lendir permukaan skor berfluktuasi tetapi cenderung stagnan. Perubahan penerimaan kulit terlihat stagnan dari awal sampai akhir pengamatan dengan skor tertinggi 0,28 yang didiskripsikan sebagai 'kencang'. Kondisi ini selaras dengan hasil analisis PCA yang menunjukkan bahwa parameter kulit tidak terhubung dengan komponen 1 maupun komponen 2. Secara fisik, kulit ikan patin tebal dan liat, sehingga
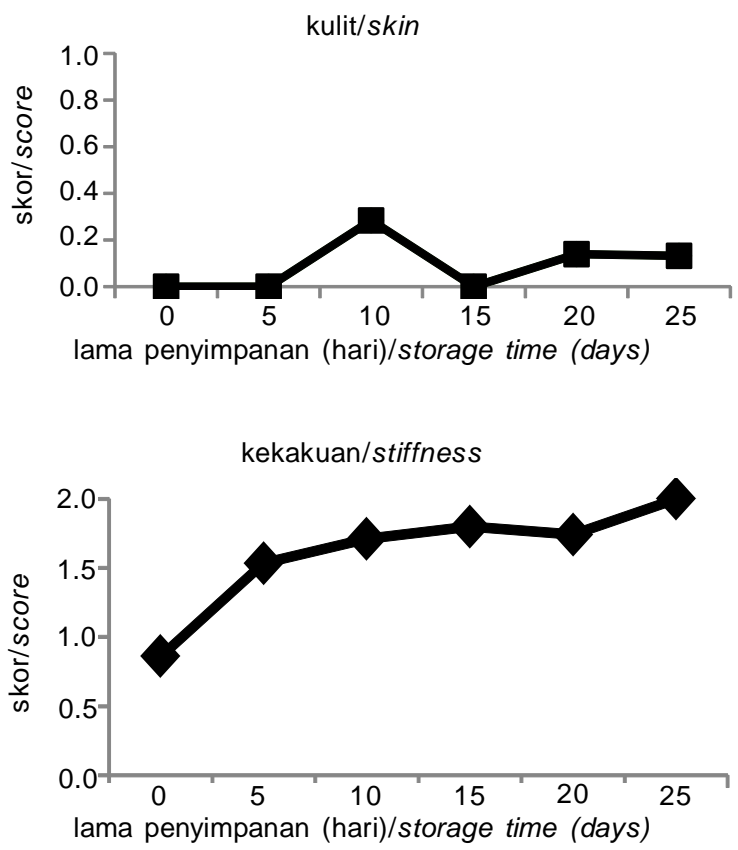

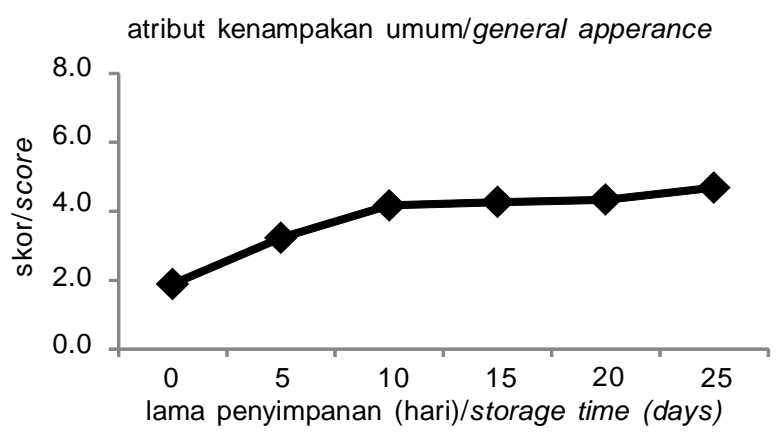

Gambar 2. Perubahan skor (DPS) atribut kenampakan umum patin segar selama pengesan

Figure 2. Score (DPS) changes of general appearance atribute of fresh pangasius during ice-storage 
sampai 25 hari penyimpanan dalam es kondisi kulit patin hampir tidak berubah. Yamaguchi, Lavety \& Love (1976) menyatakan bahwa kulit ikan patin lebih kuat dibandingkan dengan kulit ikan cod dan hake. Menurut Singh, Benjakul, Maqsood dan Kishimura (2011), kondisi tebal dan liat pada kulit patin ini kemungkinan besar berkaitan dengan ikatan silang dari hydroxylysine. Pada kulit ikan patin, hydroxylysine ditemukan pada kolagen larut asam (acid soluble collagen/ASC) maupun kolagen larut pepsin (pepsin soluble collagen/PSC) (Singh et al.). Hydroxylysine tersebut akan membentuk ikatan silang dan menyebabkan struktur kolagen menjadi kompak dan padat (Balian \& Bowes, 1977 dalam Singh et al.).

Terkait dengan parameter kekakuan, pada saat pengamatan awal, ikan dalam fase rigor (2-3 jam setelah ikan dimatikan sebelum penyimpanan) dan setelah 5-25 hari penyimpanan ikan dalam fase pasca rigor, sehingga pada pengamatan awal kondisi tubuh ikan kaku dengan nilai mendekati 1 , dan setelah penyimpanan kondisi ikan menjadi lunak dengan nilai mendekati 2. Hal ini sesuai dengan hasil penelitian Islami et al. (2014) bahwa ikan patin yang disimpan dalam es dinyatakan memasuki fase rigor 1 jam setelah dimatikan, meningkat secara perlahan dan mencapai puncaknya setelah 5 jam penyimpanan yang bertahan sampai 22 jam, kemudian berakhir setelah 22 jam penyimpanan. Perkembangan Iendir permukaan ikan patin juga tidak signifikan selama pengesan, dan nilai maksimum skor kurang lebih mencapai 1 dengan diskripsi 'tipis' yang terjadi pada akhir penyimpanan. Sesuai dengan hasil PCA, parameter lendir permukaan mempunyai korelasi kecil terhadap penilaian panelis yang termasuk dalam komponen 2 (Gambar 1). Hal ini berbeda dengan keberadaan lendir pada ikan kerapu di awal penyimpanan dalam es yang cukup tebal kemudian menurun pada penyimpanan berikutnya (Ariyani et al., 2014). Perbedaan ini salah satunya disebabkan
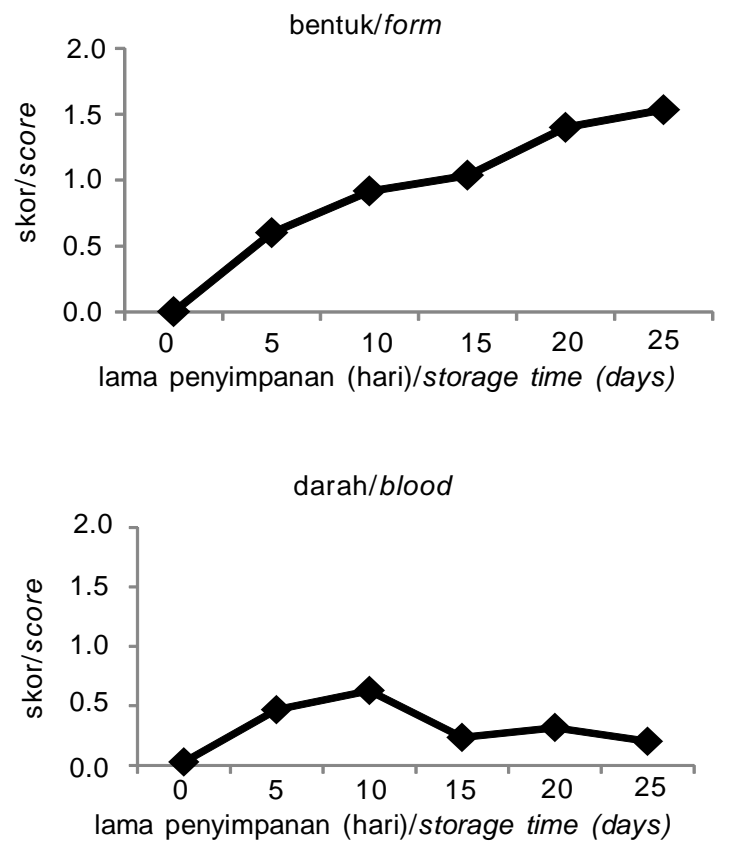

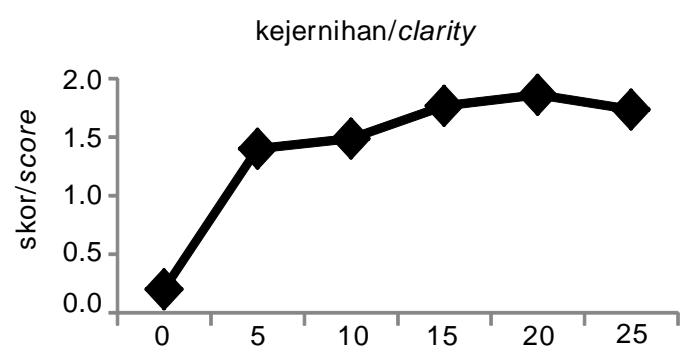

lama penyimpanan (hari)/storage time (days)

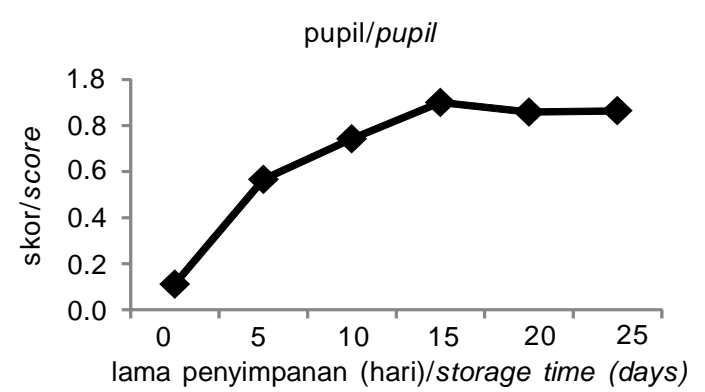

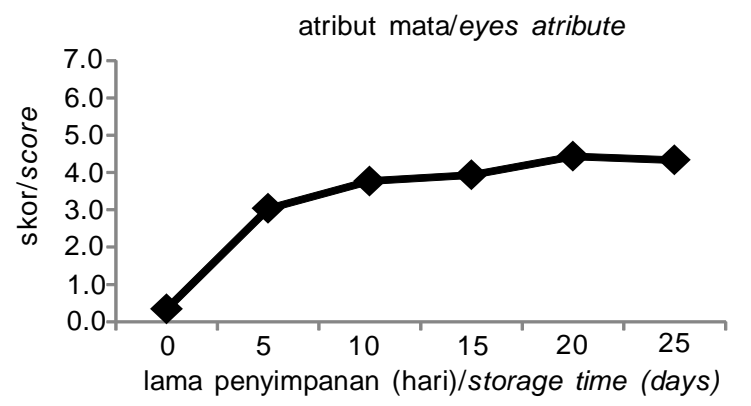

Gambar 3. Perubahan skor (DPS) atribut mata patin segar selama pengesan

Figure 3. Score (DPS) changes of eyes atribute of fresh pangasius during ice-storage 
karena perbedaan jenis ikan. Di samping itu penyimpanan dalam es memungkinkan terjadinya pelarutan lendir selama pengesan karena ikan disimpan dalam boks berinsulasi yang berisi es.

\section{Atribut Mata}

Hasil pengamatan terhadap atribut mata disajikan pada Gambar 3. Pada atribut mata, terlihat bahwa pola yang sama terjadi pada parameter kejernihan dan pupil yaitu skor meningkat sampai dengan penyimpanan hari ke 15 kemudian relatif konstan sampai akhir penyimpanan, sedangkan skor parameter bentuk mengalami peningkatan sampai akhir penyimpanan (Gambar 3). Pada pengamatan hari ke 15 penyimpanan, parameter kejernihan mencapai skor 1,8 dengan diskripsi di antara agak berkabut (nilai 1) dan berkabut (nilai 2), sedangkan parameter pupil mencapai skor 0,9 atau mendekati 1 dengan deskripsi tidak kelihatan. Parameter bentuk mencapai skor maksimum 1,5 pada akhir penyimpanan dengan deskripsi antara agak cekung (skor 1) dan cekung (skor 2). Dari perubahan ketiga parameter tersebut terlihat bahwa dengan berjalannya waktu penyimpanan terjadi penurunan kesegaran yang ditunjukkan oleh kenaikan skor ketiga parameter. Berbeda dengan parameter yang lain, skor parameter darah tidak mengalami peningkatan secara nyata
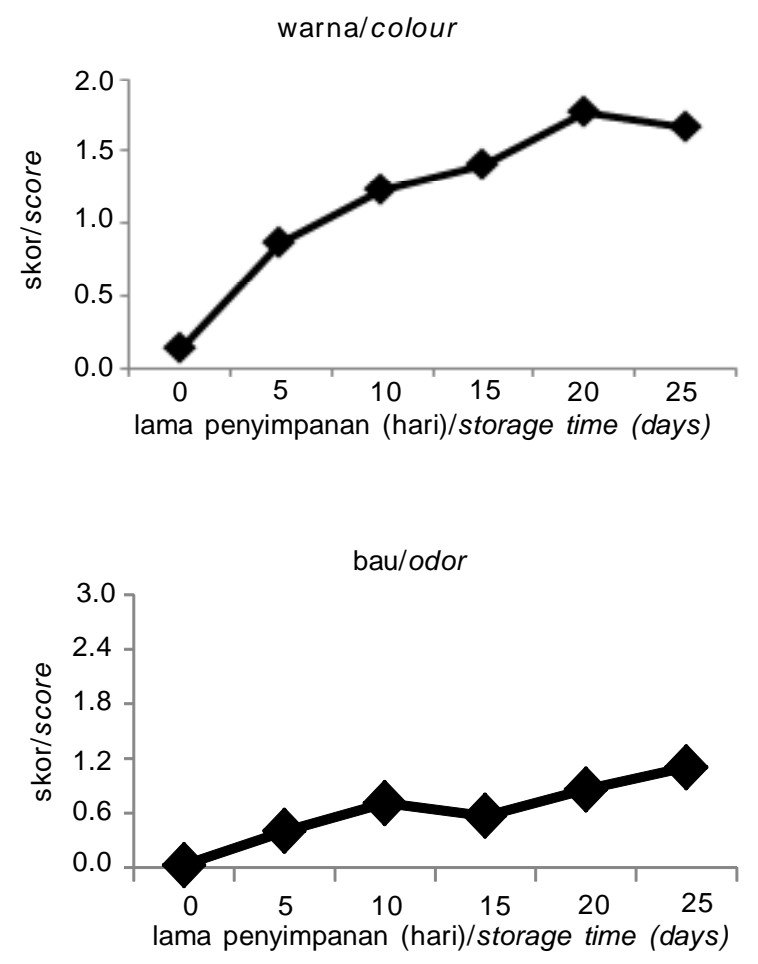

selama penyimpanan dalam es. Skor maksimum parameter darah 0,6 dengan diskripsi antara tidak berdarah (nilai 0 ) dan agak berdarah (nilai 1) yang dicapai pada penyimpanan hari ke 10 , kemudian terjadi penurunan skor sampai akhir penyimpanan. Hal ini sejalan dengan hasil PCA, yang menunjukkan bahwa parameter darah pada mata termasuk ke dalam komponen 2 (PCA2) dengan relevansi rendah terhadap penilaian panelis (Gambar 1).

Pola penurunan kesegaran ikan selama pengesan berbeda dengan pola penurunan kesegaran pada penyimpanan suhu ruang, yaitu pada penyimpanan suhu ruang, parameter keberadaan darah pada mata terlihat nyata dengan bertambahnya waktu penyimpanan. Menurut Rahman dan Olley (1984), pada penurunan mutu blue grenadier (Macruronus novaezelandiae) dan whiting (Haletta semifasciata) segar selama pengesan, keberadaan darah pada mata tidak terlihat sampai penyimpanan 9 hari, dan darah mulai sedikit terlihat setelah penyimpanan 12 hari atau lebih.

\section{Atribut Insang}

Perubahan skor pada atribut insang disajikan pada Gambar 4, yang memperlihatkan bahwa untuk parameter warna terjadi peningkatan skor yang hampir

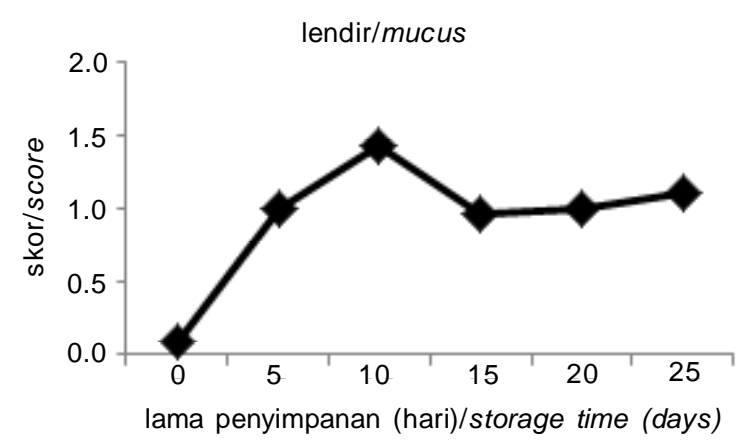

atribut insang/gills atribute

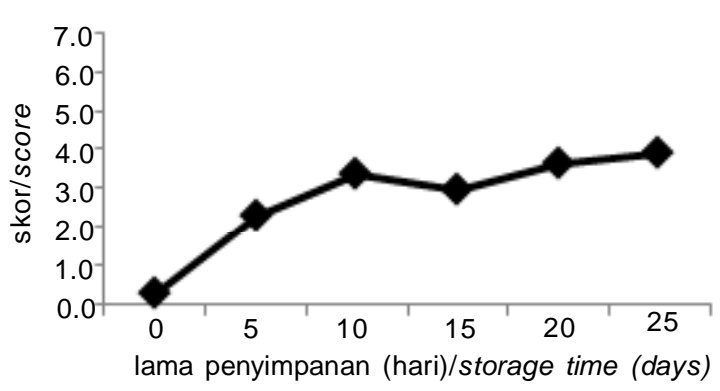

Gambar 4. Perubahan skor (DPS) atribut insang patin segar selama pengesan. Figure 4. Score (DPS) changes of gills atribute of fresh pangasius during ice-storage. 
linier sampai dengan 20 hari penyimpanan, kemudian cenderung tidak berubah pada sisa waktu penyimpanan. Pada hari ke 20 , skor yang diperoleh 1,8 dengan deskripsi mendekati sangat pudar. Perubahan warna insang yang menjadi pudar selama penyimpanan dalam es sering terjadi karena insang terendam cairan hasil pencairan es selama penyimpanan. Skor parameter bau insang terlihat meningkat perlahan selama pengesan dan pada akhir penyimpanan mencapai skor 1,10 dari skor maksimal 3,0 dengan deskripsi amis. Hasil pengamatan Massaquoi, Sveinsdottir dan Martinsdottir (2011) terhadap ikan cod selama pengesan juga menunjukkan bahwa skor parameter bau insang meningkat perlahan di awal waktu penyimpanan dan pada akhir penyimpanan (18 hari pengamatan) tidak mencapai skor maksimal (mencapai skor 2,0 dari skor maksimal 3,0). Sebaliknya, pengamatan terhadap ikan herring selama pengesan menunjukkan bahwa skor parameter warna dan bau insang berfluktuasi selama penyimpanan tetapi pada akhir penyimpanan mencapai skor maksimum (Mai, Martinsdottir, Sveinsdottir \& Olafsdottir. 2009). Perbedaan jenis ikan maupun cara penanganan memberikan perubahan parameter sensori yang berbeda. Skor parameter lendir insang pada penelitian ini meningkat secara linier yang mencapai skor 1,0 sampai 5 hari penyimpanan, kemudian meningkat lagi sampai 10 hari penyimpanan dan cenderung konstan pada sisa waktu penyimpanan. Ditinjau dari hasil PCA,

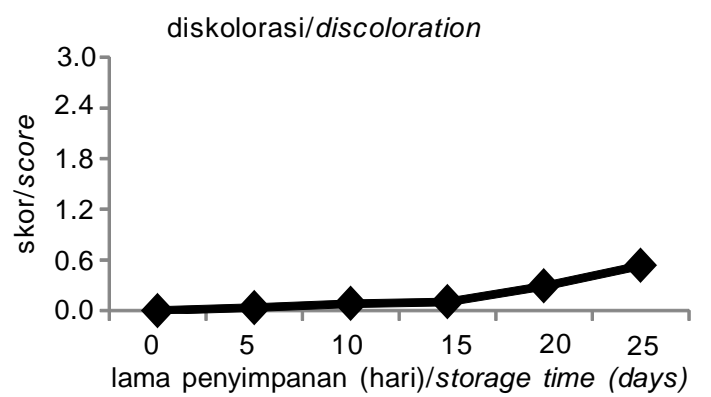

parameter lendir insang mempunyai relevansi rendah terhadap penilaian panelis dan termasuk ke dalam kelompok 2 (Gambar 1). Dalam penelitiannya, Mai et al., tidak memasukkan parameter lendir dalam skala penilaian.

\section{Atribut Perut}

Gambar 5 menyajikan pola perubahan atribut perut yang terdiri dari parameter diskolorasi dan kekakuan selama pengesan ikan patin. Peningkatan waktu penyimpanan ternyata tidak mencerminkan peningkatan skor parameter diskolorasi secara signifikan, karena sampai dengan 25 hari penyimpanan, skor masih 0,5 yang dideskripsikan di antara tidak ada diskolorasi (skor 0), dan diskolorasi terdeteksi (skor 1). Hal ini sesuai dengan hasil PCA yang menunjukkan bahwa parameter diskolorasi perut masuk di kelompok 2 yang mempunyai korelasi rendah terhadap penilaian panelis (Gambar 1). Skor parameter kekakuan baru meningkat pada 10 hari penyimpanan dengan skor 0,4 kemudian relatif konstan sampai penyimpanan 20 hari dan terlihat meningkat pada akhir penyimpanan menjadi 0,9 dengan deskripsi mendekati lunak. Kondisi ini mencerminkan bahwa sampai akhir penyimpanan di mana ikan sudah dinyatakan ditolak panelis, kondisi perut belum pecah. Karakteristik dari kulit ikan patin yang kuat dan liat sebagaimana dinyatakan Singh et al. (2011) turut berkontribusi dalam melindungi jaringan daging di bagian perut sehingga sampai akhir

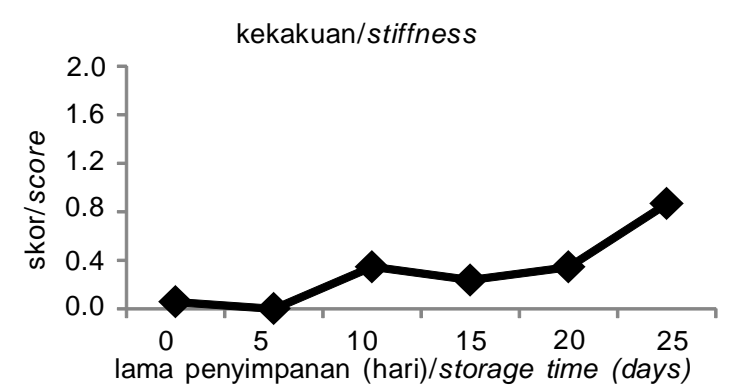

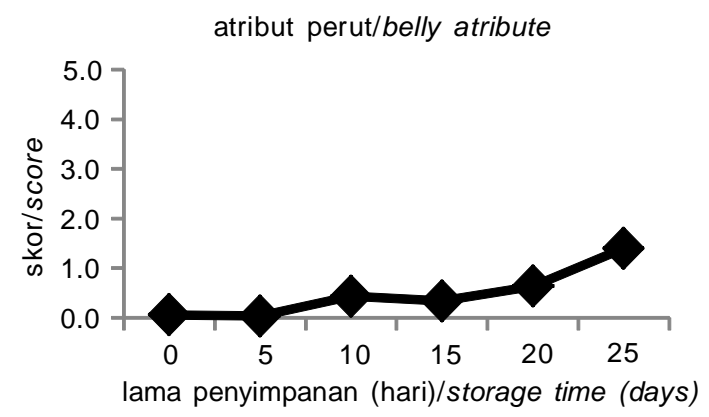

Gambar 5. Perubahan skor (DPS) atribut perut patin segar selama pengesan

Figure 5. Score (DPS) changes of belly atribute of fresh pangasius during ice-storage 
penyimpanan tidak menunjukkan deteriorasi yang signifikan. Setiap jenis ikan mempunyai pola penurunan kesegaran yang berbeda pula. Pada ikan nila yang disimpan dalam es, kondisi perut ikan masih dinyatakan kencang sampai 9 hari penyimpanan dan skor baru meningkat secara siknifikan setelah 15 hari pengesan dengan kondisi lunak (Ariyani \& Dwiyitno, 2010), sedangkan ikan hering yang disimpan pada suhu es telah lunak di awal penyimpanan (David, Magnusson \& Palmadottir, 2006).

\section{Atribut Anus}

Atribut yang juga diamati selama pengesan adalah anus dengan parameter kondisi dan bau (Gambar 6). Pengamatan terhadap kondisi anus memperlihatkan bahwa skor naik perlahan sampai 15 hari penyimpanan mencapai skor 0,2 dan di akhir penyimpanan skor mencapai 0,9 dengan deskripsi berair. Berdasarkan hasil PCA (Gambar 1), parameter kondisi anus termasuk di kelompok 2 (PC2) dengan relevansi rendah terhadap penilaian panelis. Hal ini sejalan dengan Sant'Ana et al. (2011) yang mengamati perubahan kondisi anus pada ikan blackspot seabream selama pengesan di mana sampai akhir penyimpanan kondisi anus masih memiliki skor 1 dari nilai maksimum 2. Sedikit berbeda dengan kondisi anus, bau anus mempunyai skor yang meningkat relatif konstan sampai akhir penyimpanan. Pada 5 hari penyimpanan parameter bau anus mempunyai skor 0,6 yang dideskripsikan di antara segar (skor 0) dan normal (skor 1), dan di akhir penyimpanan memiliki skor bau 1,6 yang dideskripsikan di antara netral (skor 1) dan amis (skor 2).

\section{Atribut Rongga Perut}

Di antara 6 atribut, atribut rongga perut dengan parameter stains dan darah memperlihatkan bahwa skor meningkat selama penyimpanan dalam es dengan peningkatan yang relatif konstan (Gambar 7). Hal ini menunjukkan keselarasan dengan hasil PCA bahwa parameter stains rongga perut mempunyai relevansi tinggi terhadap penilaian panelis dan termasuk dalam kelompok 1 (PC1), sedangkan parameter darah rongga perut mempunyai relevansi dengan kedua komponen (PC1 dan PC2) tetapi cenderung masuk ke kelompok 1 (Gambar 1). Pada awal penyimpanan, parameter stains pada perut terlihat bercahaya, warna spesifik dengan darah pada rongga yang berwarna merah, namun pada akhir penyimpanan stains terlihat keabu-abuan dengan skor 1,2 dan parameter darah mencapai nilai 1,0 dengan warna merah gelap. Skor pada akhir penyimpanan tersebut ternyata masih belum mencapai skor maksimal (2). Pada pola penurunan kesegaran ikan

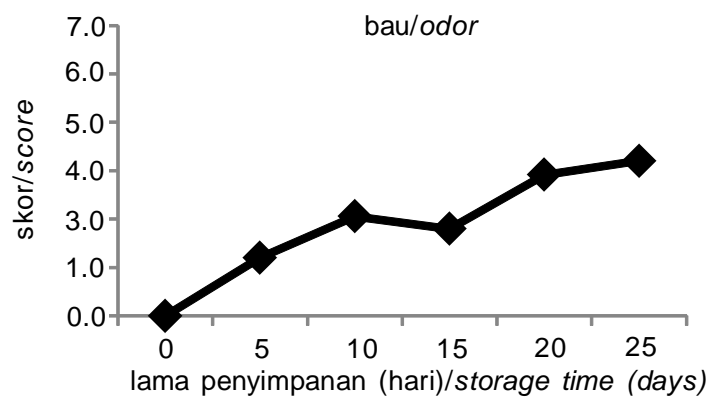

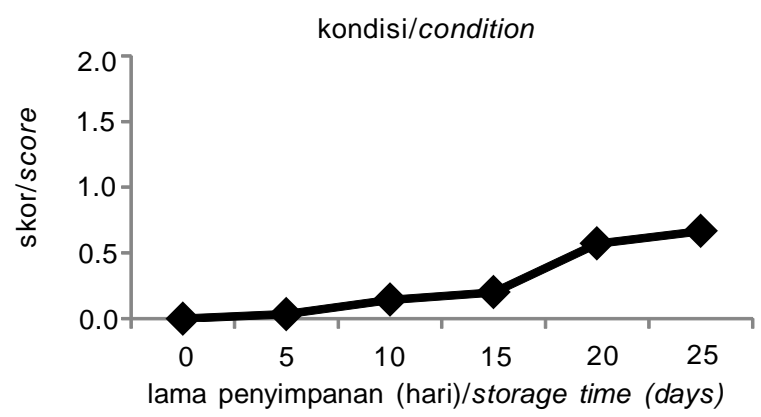

atribut anus/vent atribute

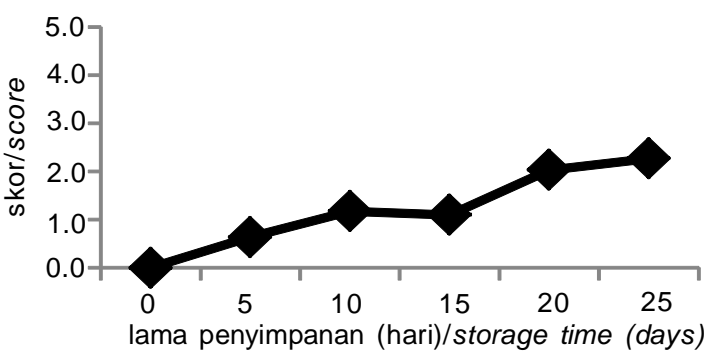

Gambar 6. Perubahan skor (DPS) atribut anus patin segar selama pengesan

Figure 6. Score (DPS) changes of vent atribute of fresh pangasius during ice-storage 

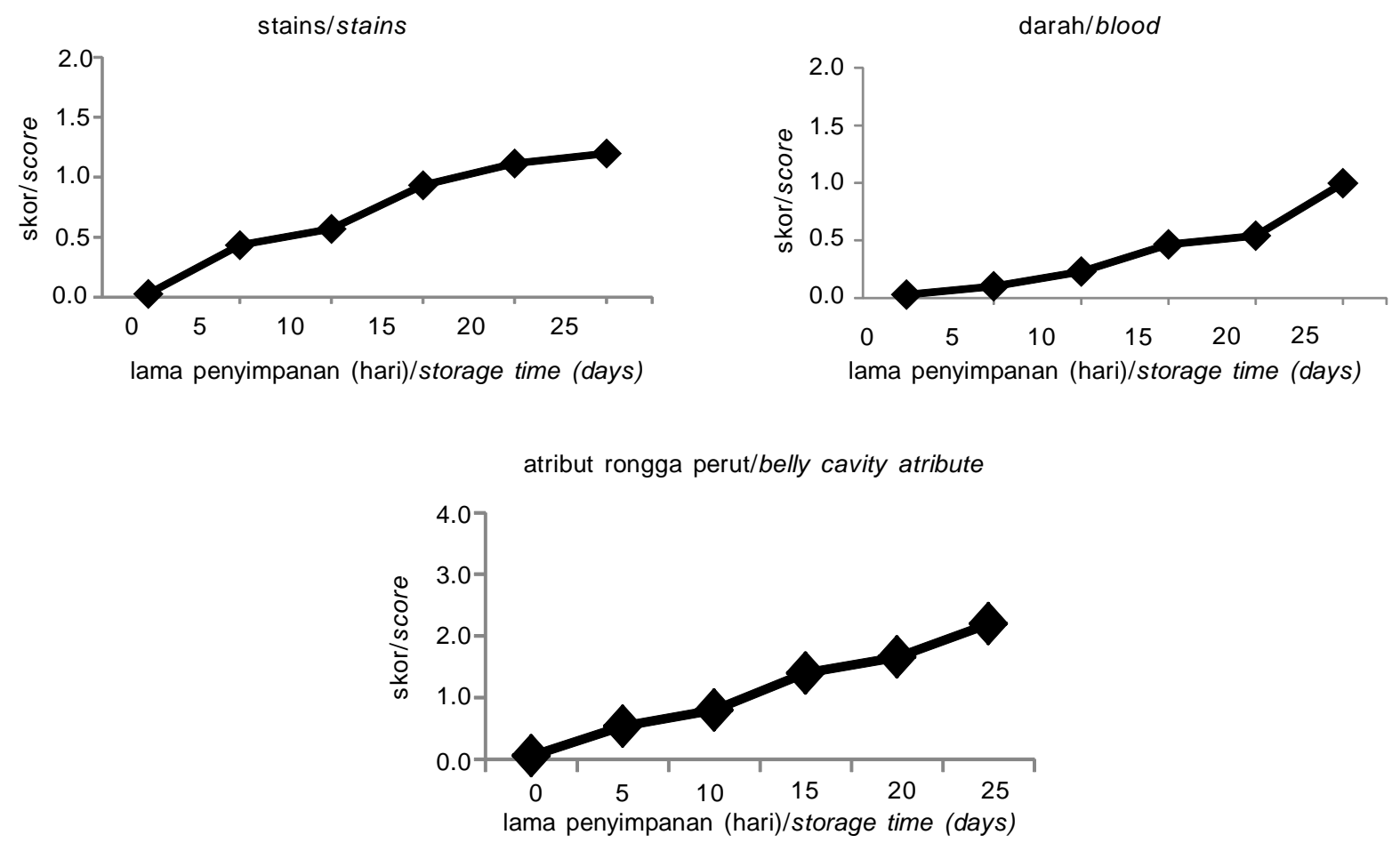

Gambar 7. Perubahan skor (DPS) atribut rongga perut patin segar selama pengesan Figur 7. Score (DPS) changes of belly cavity atribute of fresh pangasius during ice-storage

nila selama pengesan, parameter stains maupun darah pada atribut rongga perut mencapai skor maksimal yaitu 2 (Ariyani \& Dwiyitno, 2010). Hal ini mengindikasikan bahwa deteriorasi rongga perut ikan nila relatif lebih cepat dibandingkan dengan ikan patin.

\section{Pembahasan Umum}

Berdasarkan hasil tampilan grafik untuk semua parameter, maka terlihat bahwa penjabaran dari masing-masing parameter, telah sesuai dengan hasil PCA. Apabila dikelompokkan berdasarkan relevansinya terhadap perubahan kesegaran patin yang tercermin dari penilaian panelis, maka terdapat 3 kelompok parameter yakni 1) kelompok parameter yang mempunyai relevansi tinggi terhadap penilaian panelis, termasuk di dalamnya kenampakan, warna insang, kekakuan tubuh, kejernihan mata, bentuk mata, bau insang, bau anus, dan stains rongga perut, 2) kelompok parameter yang mempunyai relevansi

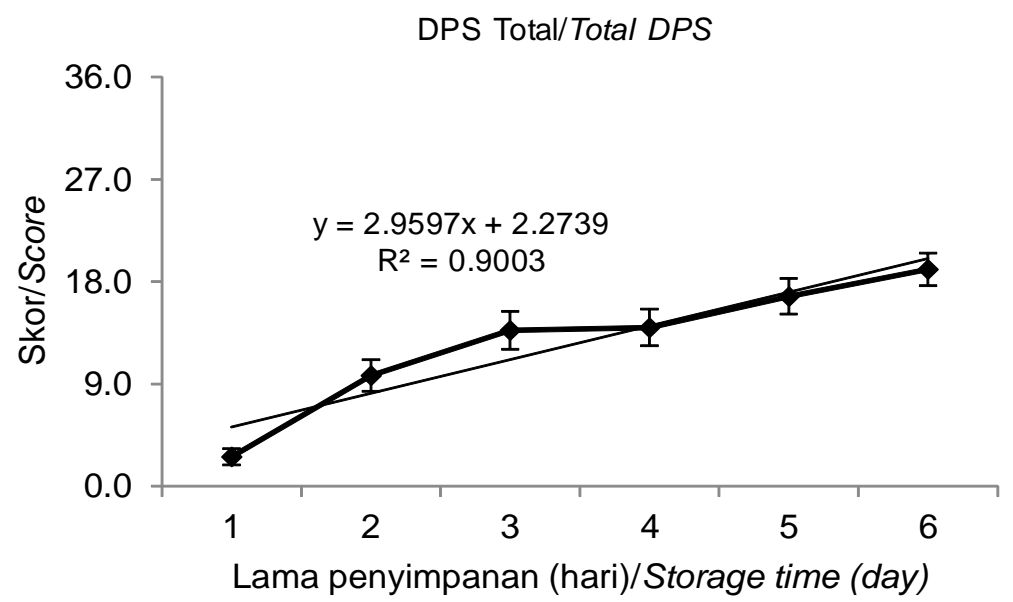

Gambar 8. Perubahan DPS total ikan patin segar selama pengesan.

Figure 8. The changes of total demerit point score of fresh pangasius during ice-storage. 
rendah terhadap penilaian panelis, termasuk di dalamnya adalah darah di mata, lendir permukaan, lendir insang, kekakuan perut, diskolorasi perut, dan kondisi anus dan 3) kelompok parameter yang mempunyai relevansi sedang terhadap penilaian panelis yaitu pupil mata dan darah rongga perut. $\mathrm{Di}$ luar kelompok 1-3, terdapat 1 parameter yakni kulit yang tidak mempunyai relevansi terhadap penilaian panelis. Peninjauan kembali terhadap parameter yang mempunyai relevansi rendah terhadap penilaian panelis perlu dilakukan dengan merevisi skala skor pada lembar penilaian. Adapun untuk parameter yang tidak mempunyai relevansi terhadap penilaian panelis disarankan untuk dihilangkan dari lembar penilaian. Perkiraan revisi lembar penilaian untuk ikan patin segar terlampir (Lampiran 2). Melalui revisi pada lembar penilain untuk kesegaran ikan patin selama pengesan, diharapkan penggunaan lembar penilaian menjadi lebih efektif dan hasil penilaian lebih realistis.

Penjumlahan skor dari semua parameter sensori pada masing-masing atribut yang mempunyai relevansi tinggi maupun rendah terhadap penilaian panelis merupakan nilai total demerit point score (DPS). Gambar 8 menyajikan hubungan antara DPS dengan waktu penyimpanan pada pengamatan ikan patin segar selama pengesan. Selama waktu penyimpanan, DPS terlihat meningkat seiring dengan bertambahnya waktu penyimpanan dengan kenaikan yang relatif konstan. Pada akhir penyimpanan ( 25 hari penyimpanan), ikan patin segar yang disimpan dalam es ditolak panelis dengan kriteria kenampakan umum agak kusam (skor 5), mata berkabut, cekung dan pupil tidak terlihat (skor 4,3), insang sangat pudar, lendir tipis dan berbau amis (skor 3,7 ), perut lunak dan sedikit terjadi diskolorasi (skor 1,4), anus agak berair dan berbau amis (skor 2,3), stains pada rongga perut berwarna abu-abu dan darah berwarna merah gelap (skor 2,2). Apabila masing-masing atribut dijumlahkan maka DPS total pada penyimpanan 25 hari sebesar 18,8. Hal ini sejalan dengan Hossain et al. (2005) yang mengamati perubahan pada parameter sensori ikan patin Thai pangas (Pangasius sutchi) dan menyatakan bahwa ikan patin segar yang disimpan dalam kotak berinsulasi ditolak panelis pada penyimpanan 25 hari, sedangkan Viji, Tanuja, Ninan, Zynudheen dan Lalitha (2014) menyatakan bahwa sutchi catfish (Pangasianodon hypophthalmus) yang disimpan dalam es ditolak secara sensori pada hari ke-20. Perbedaan jenis ikan memberikan pola penurunan kesegaran yang berbeda sebagaimana penolakan panelis terhadap ikan nila selama pengesan yang terjadi pada penyimpanan 18 hari dengan skor DPS total 25,9 (Ariyani \& Dwiyitno, 2010), sedangkan pada ikan kerapu yang dies, penolakan panelis terjadi pada penyimpanan 21 hari dengan skor DPS 23 (Ariyani et al., 2014).

\section{KESIMPULAN}

Berdasarkan hasil penelitian terhadap penurunan kesegaran secara sensori terhadap patin segar selama pengesan, maka dapat disimpulkan sebagai berikut.

- Parameter utama yang menentukan perubahan secara signifikan pada atribut sensori patin segar dan mempunyai relevansi tinggi terhadap penilaian panelis adalah parameter kenampakan dan kekakuan pada atribut kenampakan umum, parameter kejernihan dan bentuk pada atribut mata, parameter warna dan bau pada atribut insang, parameter bau pada atribut anus, dan parameter stains pada atribut rongga perut.

- Beberapa parameter yang relevansinya rendah terhadap penilaian panelis pada penurunan kesegaran patin antara lain parameter lendir pada atribute kenampakan umum, parameter darah pada atribut mata, parameter lendir pada atribute insang, parameter kekakuan dan diskolorasi pada atribut perut dan parameter kondisi pada atribut anus.

- Parameter yang tidak mempunyai relevansi terhadap penilaian panelis pada penurunan kesegaran patin adalah kulit pada atribut kenampakan umum.

- Parameter yang tidak mempunyai relevansi terhadap penilaian panelis disarankan untuk dihilangkan dari lembar penilaian, sedangkan parameter yang relevansinya rendah disarankan untuk direvisi skala skornya pada lembar penilaian.

- Lama penyimpanan patin segar sampai dinyatakan ditolak panelis adalah 25 hari

\section{UCAPAN TERIMA KASIH}

Terima kasih penulis sampaikan kepada Sdr Hedi Indra Januar yang telah membantu dalam analisis statistik menggunakan metoda PCA.

\section{DAFTAR PUSTAKA}

Ariyani, F. \& Dwiyitno. (2010). Kajian Sensori dengan Metode Demerit Point Score terhadap Penurunan Kesegaran Ikan Nila selama Pengesan. Jurnal Pascapanen dan Bioteknologi Kelautan dan Perikanan 5(2), 141-152. ISSN. 1907-9133

Ariyani, F., Murtini, J.T., \& Andayani, F. (2011). Penelitian Hubungan Parameter Sensori (Metode Demerit Point Score), Kimia dan Mikrobiologi pada Kemunduran Mutu Ikan Nila selama Pengesan. Jurnal Pascapanen dan Bioteknologi Kelautan dan Perikanan, 6(1), 69-80. ISSN. 1907-9133

Ariyani, F., Yenni, Y., \& Riyanto, R. (2014). Correlation of Demerit Point Score (DPS) and Chemcal Parameters 
on Quality of Fresh Estuary Grouper (Epinephelus tauvina) during Storage in Ice. Squalen : Bulletin of Marine and Fisheries Postharvest and Biotechnology. 9(2), 45-54

Bernardi, D.C., Mársico, E.T., \& de Freitas, M.Q. (2013). Quality Index Method (QIM) to assess the freshness and shelf life of fish. Braz. Arch. Biol. Technol, 56 (4). $14 \mathrm{pp}$.

Branch, A.C. \& Vail, A.M.A. (1985) Bringing fish inspection into the computer age. Food Technol. Aust, 37 (8), 352-355

Bremner, H.A., Statham, J.A. \& Sykes, S.J. (1985). Tropical species from North-West shelf of Australia: Sensory assessment and acceptability of fish stored on ice. In Reilly, A. (ed.) Spoilage of Tropical Fish and Product Development. Proceeding of a Symposium held in conjunction with the Sixth Session of the Indo-pacific Fishery Commision Working Party on Fish Technology and Marketing. RMIT, Melbourne, Australia, 23-26 October 1984. Rome: FAO: 41-53.

Badan Standardisasi Nasional. (2011). Petunjuk Pengujian Organoleptik dan atau Sensori pada Produk Perikanan. (SNI 2347 : 2011). Jakarta : BSN

Ghaly, A.E., Dave, D., Budge, S., \& Brooks, M.S. (2010). Fish Spoilage Mechanisms and Preservation Techniques: Review. American Journal of Applied Sciences, 7(7), 859-877.

Green-Petersen, D.M.B. (2010). Sensory Quality of Seafood - in the chain from catch to consumption. Thesis. National Food Institute-Technical University of Denmark Divsion of Seafood Research. 82 pp

Hammer O., Harper D.A.T., \& Ryan P.D. (2001). Past: Palaeontological Statistics Software package for nd data analysis. Palaeontological Electronic, 4(1), 9.

Heinz, G. \& Hautzinger, P. (2007). Simple Test Methods For Meat Products. Bangkok, Food And Agriculture Organization of The United Nations-Regional Office For Asia and The Pacific.

Hyldig, G., \& Green-Peterson. (2004). Quality Index Method. An Objective Tool for Determination of Sensory Quality. J. Aquatic Food Product Technology, 13(4), 71-80

Hyldig, G., Bremner, A., Martinsdottir, E., \& Schelvis, R. (2007). Quality Index Method. In Nollet, et al. Handbook of Meat, Poultry and Sefood Qualit. lowa USA : Blackwell Publishing Professional: 529-548

Huidobro, A. Pastor, A \& M. Tejada, M. (2000). Quality Index Method Developed for Raw Gilthead Seabream (Sparus aurata) In Sensory and Nutritive Qualities of Food. Journal of Food Science, 65(7), 1202-1205

Huss, H.H. (1995). Quality and Quality Changes in Fresh Fish. FAO Fisheries Technical Paper. 348. Rome., FAO of the United Nations. $195 \mathrm{p}$
Ikasari, D. \& Suryaningrum, T.D. (2015). Quality changes of pangasius fillets during ice storage. Squalen Bull. of Mar. \& Fish. Postharvest \& Biotech, 10(3), 109120

Islami, S,N., Reza, M.S., Mansur, M.A., Hossain, M.I., Shikha, F.H., \& Kamal, M. (2014). Rigor index, fillet yield and proximate composition of cultured striped catfish (Pangasianodon hypophthalmus) for its suitability in processing industries in Bangladesh. Journal of Fisheries, 2(3), 157-162

Lillian, C, Einarsson, H., \& Eythorsdottir, A. (2007). Alternative Methods For Fish Grading. Fisheries Training Programme, The United Nations University. Iceland. 30 pp.

Luten, G., Dalgaard, J., P., Careche, M., Verrez-Bagnis, V., Martinsdottir, E. \& Heia, K. (1997). Methods to Determine the Freshness of Fish in Research and Industry. Trends in Food Science and Technology. 8, 258-265.

Mai, N.T.T., Martinsdóttir,E., Sveinsdóttir, K., Olafsdóttir, G., \& Arason, S. (2009). Application of Quality Index Method, Texture Measurements and Electronic Nose to Assess the Freshness of Atlantic Herring (Clupea harengus) Stored in Ice. World Academy of Science, Engineering and Technology. 57, 283-289.

Massaquoi, H., Sveinsdóttir, K., \& Martinsdóttir, E. (2011). Quality Changes of Fish from Catch to Processing and During Storage with Focus on Cooling Practices and Practical Application of Sierra Leone. Fisheries Training Programme. United Nation University. Iceland. $45 \mathrm{pp}$

Rahman, H.A. \& Olley, J. (1984). Assessment of Sensory Techniques for Quality Assessment of Australian Fish. CSRIO. Tasmanian Regional Laboratory. Occasional Paper No. 8. 84 pp.

Sant'Ana, L.S., Soares, S., \& Vaz-Pires, P. (2011). Development of a quality index method (QIM) sensory scheme and study of shelf-life of ice-stored blackspot seabream (Pagellus bogaraveo). LWT - Food Science and Technology, 4, 2253-2259.

Singh, P., Benjakul, S., Maqsood, S. \& Kishimura, H. (2011). Isolation and characterisation of collagen extracted from the skin of striped catfish (Pangasianodon hypophthalmus). Food Chemistry, 124, 97-105.

Viji, P., Tanuja, S., Ninan, G., ,Zynudheen A.A., \& Lalitha, K.V. (2014). Quality characteristics and shelf life of sutchi cat fish (Pangasianodon hypophthalmus) steaks during refrigerated storage. International Journal of Agriculture and Food Science Technology, 5(2): 105-116.

Yamaguchi, K., Lavety, J., \& Love, R.M. (1976). The connective tissues of fish VIII. Comparative studies on hake, cod and catfish collagens. J. Fd Technol. 11, 389-399. 


\section{LAMPIRAN/APPENDIX1.}

Lembar penilaian DPS sebelum revisi/DPS score sheet for a whole pangasius before revision

\begin{tabular}{|c|c|c|c|c|}
\hline $\begin{array}{l}\text { Parameter Kualitas/ } \\
\text { Quality Parameters }\end{array}$ & $\begin{array}{c}\text { Karakter/ } \\
\text { Characteristics }\end{array}$ & $\begin{array}{l}\text { Skor/ } \\
\text { Score }\end{array}$ & $\begin{array}{l}\text { Deskripsi/ } \\
\text { Description }\end{array}$ & $\begin{array}{l}\text { Kode } \\
\text { Sampel/ } \\
\text { Sample } \\
\text { Code }\end{array}$ \\
\hline \multirow{12}{*}{$\begin{array}{l}\text { Kenampakan Umum/ } \\
\text { General Appearance }\end{array}$} & \multirow{4}{*}{$\begin{array}{l}\text { Kenampakan/ } \\
\text { Appearance }\end{array}$} & 0 & Sangat cerah/Very Bright & \\
\hline & & 1 & Cerah/Bright & \\
\hline & & 2 & Agak kusam/Slightly dull & \\
\hline & & 3 & Kusam/Dull & \\
\hline & \multirow[t]{2}{*}{ Kulit/Skin } & 0 & Kencang/ Firm & \\
\hline & & 1 & Lunak/ Soft & \\
\hline & \multirow{3}{*}{$\begin{array}{l}\text { Lendir Permukaan/Surface } \\
\text { Mucus }\end{array}$} & 0 & Tidak ada/ not slimy & \\
\hline & & 1 & Tipis/Slightly slimy & \\
\hline & & 2 & Tebal/Slimy & \\
\hline & \multirow[t]{3}{*}{ Kekakuan/Firmness } & 0 & Sebelum rigor/Pre-rigor & \\
\hline & & 1 & Rigor/Rigor & \\
\hline & & 2 & Sesudah rigor/Post-rigor & \\
\hline \multirow{11}{*}{$\begin{array}{l}\text { Mata/ } \\
\text { Eyes }\end{array}$} & \multirow{3}{*}{ Kejernihan/Clarity } & 0 & Jernih/Clear & \\
\hline & & 1 & Agak berkabut/ Slightly cloudy & \\
\hline & & 2 & Berkabut/ Cloudy & \\
\hline & \multirow[t]{3}{*}{ Bentuk/Form } & 0 & Normal/Normal & \\
\hline & & 1 & Agak cekung/ Slightly sunken & \\
\hline & & 2 & Cekung/Sunken & \\
\hline & \multirow[t]{2}{*}{ Pupil/Pupil } & 0 & Kelihatan/Visible & \\
\hline & & 1 & Tidak kelihatan/Not visib/e & \\
\hline & \multirow[t]{3}{*}{ Darah/Blood } & 0 & Tidak berdarah/No blood & \\
\hline & & 1 & Agak berdarah/Slightly bloody & \\
\hline & & 2 & Sangat berdarah/Very bloody & \\
\hline \multirow{6}{*}{$\begin{array}{l}\text { Perut/ } \\
\text { Belly }\end{array}$} & \multirow[t]{4}{*}{ Diskolorasi/Discoloration } & 0 & Tidak ada/Absent & \\
\hline & & 1 & Terdeteksi/Detectable & \\
\hline & & 2 & Sedang/Moderate & \\
\hline & & 3 & Banyak/Exessive & \\
\hline & \multirow[t]{2}{*}{ Kekakuan/Firmness } & 0 & Kencang/Firm & \\
\hline & & 1 & Lunak/Soft & \\
\hline \multirow{10}{*}{$\begin{array}{l}\text { Insang/ } \\
\text { Gills }\end{array}$} & \multirow[t]{3}{*}{ Warna/Colour } & 0 & Merah, spesifik/Characteristics red & \\
\hline & & 1 & $\begin{array}{l}\text { Agak gelap, agak pudar/ Slightly } \\
\text { dark, slightly faded }\end{array}$ & \\
\hline & & 2 & $\begin{array}{l}\text { Sangat gelap, sangat pudar/Very } \\
\text { dark, very faded }\end{array}$ & \\
\hline & \multirow[t]{3}{*}{ Lendir/Mucus } & 0 & Tidak ada/Absent & \\
\hline & & 1 & Tipis/Moderate & \\
\hline & & 2 & Tebal/Exessive & \\
\hline & \multirow[t]{4}{*}{ Bau/Smell } & 0 & $\begin{array}{l}\text { Segar,berminyak, rumput laut, } \\
\text { logam/Fresh oily, seewead, } \\
\text { metallic }\end{array}$ & \\
\hline & & 1 & Amis/Fishy & \\
\hline & & 2 & Basi/Stale & \\
\hline & & 3 & Busuk/Spoilt & \\
\hline
\end{tabular}




\section{LAMPIRAN/APPENDIX1.}

Lembar penilaian DPS sebelum revisi (lanjutan)/ DPS score sheet for a whole pangasius before revision (continue)

\begin{tabular}{|c|c|c|c|c|}
\hline $\begin{array}{l}\text { Parameter Kualitas/ } \\
\text { Quality Parameters }\end{array}$ & $\begin{array}{c}\text { Karakter/ } \\
\text { Characteristics }\end{array}$ & $\begin{array}{l}\text { Skor/ } \\
\text { Score }\end{array}$ & $\begin{array}{l}\text { Deskripsi/ } \\
\text { Description }\end{array}$ & $\begin{array}{c}\text { Kode } \\
\text { Sampel/ } \\
\text { Sample } \\
\text { Code }\end{array}$ \\
\hline \multirow{7}{*}{ Anus/Vent } & \multirow{3}{*}{ Kondisi/Condition } & 0 & Normal/Normal & \\
\hline & & 1 & $\begin{array}{l}\text { Agak pecah, berair/ Slightly break, } \\
\text { exudes }\end{array}$ & \\
\hline & & 2 & $\begin{array}{l}\text { Pecah, berair, terbuka/ Exessive, } \\
\text { opening }\end{array}$ & \\
\hline & \multirow{4}{*}{ Bau/Smell } & 0 & Segar/Fresh & \\
\hline & & 1 & Netral/Neutral & \\
\hline & & 2 & Am is/Fishy & \\
\hline & & 3 & Busuk/Spoilt & \\
\hline \multirow{6}{*}{$\begin{array}{l}\text { Rongga Perut/ } \\
\text { Belly Cavity }\end{array}$} & \multirow{3}{*}{ Stains/Stains } & 0 & $\begin{array}{l}\text { Bercahaya, warna spesifik/ } \\
\text { Opalescent, characteristics colour }\end{array}$ & \\
\hline & & 1 & Keabu-abuan/ Greyish & \\
\hline & & 2 & Kuning kecoklatan/Yellow-brown & \\
\hline & \multirow{3}{*}{ Darah/Blood } & 0 & Merah/Red & \\
\hline & & 1 & Merah gelap/Dark red & \\
\hline & & 2 & Coklat/Brown & \\
\hline
\end{tabular}

Skor Minimal/Minimum Score : 0

Skor Maksimal/Maximum Score : 36 
LAMPIRAN/APPENDIX2.

Lembar penilaian DPS hasil revisi/Revised DPS score sheet for a whole pangasius

\begin{tabular}{|c|c|c|c|c|}
\hline $\begin{array}{l}\text { Parameter Kualitas/ } \\
\text { Quality Parameters }\end{array}$ & $\begin{array}{l}\text { Karakteristik/ } \\
\text { Characteristics }\end{array}$ & $\begin{array}{l}\text { Skor/ } \\
\text { Score }\end{array}$ & $\begin{array}{l}\text { Deskripsi/ } \\
\text { Description }\end{array}$ & $\begin{array}{c}\text { Kode } \\
\text { Sampel/ } \\
\text { Sample } \\
\text { Code }\end{array}$ \\
\hline \multirow{12}{*}{$\begin{array}{l}\text { KenampakanUmum/ } \\
\text { General Appearance }\end{array}$} & \multirow{4}{*}{$\begin{array}{l}\text { Kenampakan/ } \\
\text { Appearance }\end{array}$} & 0 & Sangat cerah/Very Bright & \\
\hline & & 1 & Cerah/Bright & \\
\hline & & 2 & Agak kusam/Slightly dull & \\
\hline & & 3 & Kusam/Dull & \\
\hline & \multirow[t]{2}{*}{ Kulit/Skin } & 0 & Kencang/Firm & \\
\hline & & 1 & Lunak/Soft & \\
\hline & \multirow{3}{*}{$\begin{array}{l}\text { Lendir Permukaan/Surface } \\
\text { Mucus }\end{array}$} & 0 & Tidak ada/ not slimy & \\
\hline & & 1 & Tipis / Slightly slimy & \\
\hline & & 2 & Tebal/ Slimy & \\
\hline & \multirow[t]{3}{*}{ Kekakuan/Firmness } & 0 & Sebelum rigor/Pre-rigor & \\
\hline & & 1 & Rigor/Rigor & \\
\hline & & 2 & Sesudah rigor/Post-rigor & \\
\hline \multirow{11}{*}{$\begin{array}{l}\text { Mata/ } \\
\text { Eyes }\end{array}$} & \multirow[t]{3}{*}{ Kejernihan/Clarity } & 0 & Jernih/Clear & \\
\hline & & 1 & $\begin{array}{l}\text { Agak berkabut/ Slightly } \\
\text { cloudy }\end{array}$ & \\
\hline & & 2 & Berkabut/ Cloudy & \\
\hline & \multirow[t]{3}{*}{ Bentuk/Form } & 0 & Norm al/Normal & \\
\hline & & 1 & Agak cekung/ Slightly sunken & \\
\hline & & 2 & Cekung/Sunken & \\
\hline & \multirow[t]{2}{*}{ Pupil/Pupil } & 0 & Kelihatan/Visib/e & \\
\hline & & 1 & Tidak kelihatan/Not visible & \\
\hline & \multirow[t]{3}{*}{ Darah/Blood } & 0 & Tidak berdarah/No blood & \\
\hline & & 1 & $\begin{array}{l}\text { Agak berdarah/Slightly } \\
\text { bloody }\end{array}$ & \\
\hline & & 2 & $\begin{array}{l}\text { Sangat berdarah/Very } \\
\text { bloody }\end{array}$ & \\
\hline \multirow{6}{*}{$\begin{array}{l}\text { Perut/ } \\
\text { Belly }\end{array}$} & \multirow[t]{4}{*}{ Diskolorasi/Discoloration } & 0 & Tidak ada/Absent & \\
\hline & & 1 & Terdeteksi/Detectable & \\
\hline & & 2 & Sedang/Moderate & \\
\hline & & 3 & Banyak/Exessive & \\
\hline & \multirow{2}{*}{ Kekakuan/Firmness } & 0 & Kencang/Firm & \\
\hline & & 1 & Lunak/Soft & \\
\hline \multirow[t]{10}{*}{$\begin{array}{l}\text { Insang/ } \\
\text { Gills }\end{array}$} & \multirow[t]{3}{*}{ Warna/Colour } & 0 & $\begin{array}{l}\text { Merah, } \\
\text { spesifik/Characteristics red }\end{array}$ & \\
\hline & & 1 & $\begin{array}{l}\text { Agak gelap, agak pudar/ } \\
\text { Slightly dark, slightly faded }\end{array}$ & \\
\hline & & 2 & $\begin{array}{l}\text { Sangat gelap, sangat } \\
\text { pudar/Very dark, very faded }\end{array}$ & \\
\hline & \multirow[t]{3}{*}{ Lendir/Mucus } & 0 & Tidak ada/Absent & \\
\hline & & 1 & Tipis/Moderate & \\
\hline & & 2 & Tebal/Exessive & \\
\hline & \multirow[t]{4}{*}{ Bau/Smell } & 0 & $\begin{array}{l}\text { Segar,berm inyak, rumput } \\
\text { laut, logam /Fresh oily, } \\
\text { seewead, metallic }\end{array}$ & \\
\hline & & 1 & Am is/Fishy & \\
\hline & & 2 & Basi/Stale & \\
\hline & & 3 & Busuk/Spoilt & \\
\hline
\end{tabular}




\section{LAMPIRAN/APPENDIX2.}

Lembar penilaian DPS hasil revisi (lanjutan)/

Revised DPS score sheet for a whole pangasius (continue)

\begin{tabular}{|c|c|c|c|c|}
\hline $\begin{array}{l}\text { Parameter Kualitas/ } \\
\text { Quality Parameters }\end{array}$ & $\begin{array}{l}\text { Karakteristik/ } \\
\text { Characteristics }\end{array}$ & $\begin{array}{l}\text { Skor/ } \\
\text { Score }\end{array}$ & $\begin{array}{l}\text { Deskripsi/ } \\
\text { Description }\end{array}$ & $\begin{array}{c}\text { Kode } \\
\text { Sampel/ } \\
\text { Sample } \\
\text { Code }\end{array}$ \\
\hline \multirow{5}{*}{ Anus/Vent } & \multirow[b]{2}{*}{ Kondisi/Condition } & 0 & Normal/Normal & \\
\hline & & 1 & $\begin{array}{l}\text { Agak pecah, berair/ Slightly } \\
\text { break, exudes }\end{array}$ & \\
\hline & \multirow{3}{*}{$\mathrm{Bau} / \mathrm{Smell}$} & 0 & Segar/Fresh & \\
\hline & & 1 & Netral/Neutral & \\
\hline & & 2 & Am is/Fishy & \\
\hline \multirow{6}{*}{$\begin{array}{l}\text { Rongga Perut/ } \\
\text { Belly Cavity }\end{array}$} & \multirow{3}{*}{ Stains/Stains } & 0 & $\begin{array}{l}\text { Bercahaya, warna } \\
\text { spesifik/Opalescent, } \\
\text { characteristics colour }\end{array}$ & \\
\hline & & 1 & Keabu-abuan/ Greyish & \\
\hline & & 2 & $\begin{array}{l}\text { Kuning kecoklatan/ Yellow- } \\
\text { brown }\end{array}$ & \\
\hline & \multirow{3}{*}{ Darah/Blood } & 0 & Merah/Red & \\
\hline & & 1 & Merah gelap/Dark red & \\
\hline & & 2 & Coklat/Brown & \\
\hline
\end{tabular}

Skor Minimal/Minimum Score $\quad: 0$

Skor Maksimal/Maximum Score : 27 
JPB Kelautan dan Perikanan Vol. 11 No. 1 Tahun 2016: 67-82 